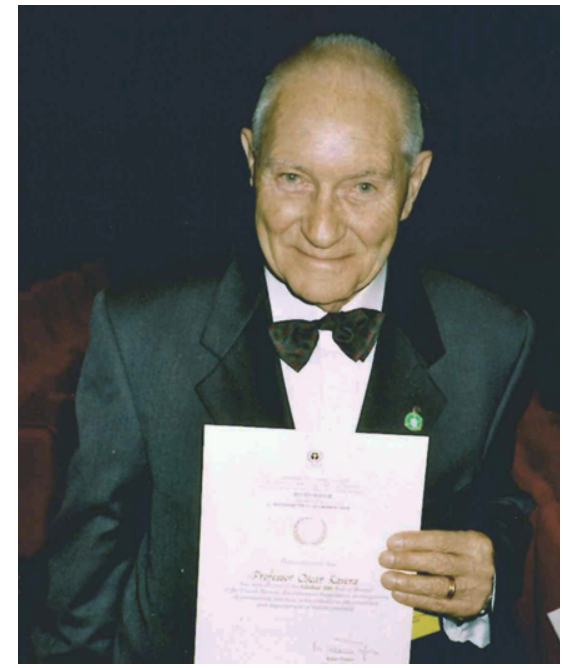

Oscar Ravera at the ceremony for his nomination as UNEP Global 500 laureate in 2001 for Environmental Achievement.

\section{IN MEMORY OF OSCAR RAVERA}

Oscar Ravera was one of the most lively and active protagonists in the field of ecology. A man of great culture, Oscar had a genuine interest in knowledge, an interest fed by his insatiable childlike curiosity. Arriving young, at Pallanza, he found fertile ground to develop his passion for aquatic ecology, a passion that led both to important scientific achievements, and to very largescale initiatives.

Those who had the fortune to work with him soon learned of his uncommon inclination to include students and young researchers in his various discussions and original projects, and of his ability to translate ideas into practice through the design and construction of novel field and laboratory instruments. Oscar, not only conceived of innovative research projects, but he also developed many new study techniques. He embodied the profile of the perfect researcher, skilled both in the field (those who saw him at work on the lakes were filled with admiration) and in the laboratory.

Thanks to the sweet memories of the years of his youth spent at Pallanza, we had the opportunity to host Oscar again at the Institute during his last fifteen years.

With him, an important piece of our limnological history and of the history of the ecological thought has gone. We have lost a friend, a teacher, and a colleague, who contributed greatly to the growth of the scientific community he pioneered.

Oscar Ravera (1925-2015) started his career in 1949 at the Istituto Italiano di Idrobiologia, under the Direction of Prof. Edgardo Baldi. Here he stayed until 1956 performing basic research in limnology, which gave him a basis for further studies on theoretical and applied problems in fresh and brackish water ecology. After two years working as a Chief of the Micropaleontological Service, Dept. of Min- ing, for the Edison Company, he carried out 30 years of scientific activity at the Joint Research Center (J.R.C.) of the Commission of the European Communities (C.E.C.). His activity made the J.R.C. one of the most important reference points in Europe in the field of aquatic ecology. After his retirement from the J.R.C. he held the Chair of Ecology at the University of Venice (Ca' Foscari) until 1997. Since 1998, his passion for research brought him back to his origins, at the Italian Institute of Hydrobiology (presently the CNR Institute of Ecosystem Studies).

Out of many ecological topics he pioneered during his long career four relevant ones were:

- contamination of lake ecosystems by radioisotopes and the biological effects of ionizing radiation

- eutrophication processes and the search for corrective strategies and interventions

- accumulation of trace metals by freshwater mussels, and the effects of trace metals on the planktonic community

- evaluation of the state of the Venice canals and the production and decomposition of macroalgae in the Lagoon of Venice.

His discovery of the great accumulation by freshwater mussels of ${ }^{54} \mathrm{Mn}$ from fall-out (100,000 times the concentration in lake water) was one of the most convincing demonstrations for modifying the European radioprotection rules on the risk of the bioconcentration of radioisotopes. The same methods used in the study of radio-contamination were transferred to the study of heavy metal pollution, producing important results in the assessment of the fate and the biological effects of low concentrations of toxic metals. His best results were obtained by applying, as a pioneer in Italy, the "mesocosms" method in tackling ecological and pollution problems. As an example, these experiments provided a better insight into the role of lake trophic conditions as an amplifier or a minimizer of the biological effects of toxic metals.

$\mathrm{He}$ was also one of the first to use fall-out radioactivity for dating lake sediments. He used short-life zooplankters as sentinels of radioactive contamination and the fate of radionuclides in lakes, and long-lived mussels as bioaccumulators of radioisotopes over time.

In addition to his scientific research, Oscar had broad involvements as adviser to the Commission of the European Communities (CEC, Bruxelles) in formulating environmental research programmes (1971-1990). He was a member of the Technical Bureau of the OECD International Programme on Eutrophication (1972-1980); a member of the Technical-Scientific Committee of the International Commission for the protection of Italian-Swiss waters (1972-1987); the scientific coordinator of the UNESCO International Expert Group on the Lagoon of Venice (1997-1999); a member of the Special Programme Panel Ecosciences of the NATO - Bruxelles (1979-1983) and several others. Also, he collaborated with the International Expert Commission, coordinated by Prof. Ph. 
Bourdeau, on the environmental impact of the mobile flood barriers on the Venice Lagoon (1998).

He numbers, among his major achievements, the promotion of ecology in Italian universities, the training of many Italian and foreign students, and helping to raise the consciousness of the general public as regards ecological concepts and the principles of environmental ethics. He was cofounder, president and emeritus member of the Italian Society of Ecology (S.It.E.). In collaboration with Prof. A. Moroni (Parma) he brought ecology to a firm footing in the academic community of Italy, National representative of the European Ecological Federation (EEF) and of the Societas Internationalis Limnologiae (SIL), he was awarded as Global 550 Laureate in 2001.

Between 1949 and 2012, Oscar authored more than 240 papers, those listed below representing only a small part of the breadth of the ecological topics that he investigated.

\section{Marina M. Manca, Nicoletta Riccardi CNR-ISE, Largo Tonolli 50 28922 Verbania Pallanza (VB) Italy}

\section{SOME SELECTED PUBLICATIONS}

Ravera O, 1955. Seasonal variation of the reproductive rate in pelagic copepods of Lake Maggiore. Proc. Int. Assoc. Theoret. Appl. Limnol. 12:436-446.

Ravera O, Tonolli V, 1956. Body size and number of eggs in Diaptomids, as related to water renewal in Mountain Lakes. Limnol. Oceanogr. 1:118-122.

Gaglione P, Ravera O, 1964. Mn-54 concentration in fall-out, water and Unio mussels of Lake Maggiore, 1960-63. Nature 204:1215-1216.

Ravera O, Premazzi G, 1972. A method to study the history of any persistent pollution in a lake by the concentration of Cs137 from fall-out in sediments. Proc. Int. Symp. "Radioecology applied to the protection of man and his environment" 1:703-722.

Baudouin MF, Ravera O, 1972. Weight, size, and chemical composition of freshwater zooplankters: Daphnia hyalina (Leydig). Limnol. Oceanogr. 17:645-649.

Ravera O, 1977. Effects of heavy metals (cadmium, copper, chromium and lead) on a freshwater snail: Biomphalaria glabrata say (Gastropoda, Prosonranchia). Malacologia 16: 231-236.

Ravera O, Parise G, 1978. Eutrophication of Lake Lugano "read" by means of planktonic remains in the sediment. Schweiz. Z. Hydrol. 40:48-50.

Ravera O, 1978. Evaluation of effects of radioactive contamination of the marine biota. Rev. Int. Oceanogr. Med. 49:147-161.

Ravera O, 1979. Considerations on the effects of pollution at community and population level. Experientia 35:710-713.

Ravera O, 1979. Biological effects of ionizing radiations in aquatic environment. In: Biological aspects of freshwater pollution. Ravera O (Ed.), Published for the Commission of the European Communities: 179-197.

Ravera O, 1981. Italy, p. 2238-228. In: E.J. Kormondi and McCormick J.F. (eds.), Handbook of contemporary developments in world ecology. Greenwood Press.

Ravera O, 1984. Considerations on some ecological principles, p. 145-162. In: J.H. Cooley and F.B. Golley (eds.), Trends in ecological research for the 1980s. Plenum Press.

Ravera O, 1984. Cadmium in freshwater ecosystems. Experientia 40:2-13.

Ravera O, 1985. Some selected examples of eutrophicated european lakes, p. 177-187. In: H.W. Nurnberg (ed.), Pollutants and their ecotoxicological significance. WileyBlackwell.

Ravera O, 1986. Effects of experimental acidification on freshwater environments. Experientia 42:507-516.

Ravera O, 1989. Degradation, protection and recovery of lake ecosystems. In: G.B. Marini-Bettolo (ed.), A modern approach to the protection of the environment. Pontificiae Academiae Scientiarum Scripta varia 75:243-266.

Ravera O, 1989. Ecological effects of acid depositions. Cheremisinoff PN (Ed.), Encyclopedia Environmental Control Technology 3: Wastewater Treatment Technology 447-486.

Ravera O, 1989. The "Enclosure" method: concepts, technology, and some examples of experiments with trace metal, p. 249272. In: A. Boudou and F. Ribeyre (eds.), Aquatic ecotoxicology: fundamental concepts and methodologies. 1. CRC Press.

Ghetti PF, Ravera O, 1990. European perspective on biological monitoring. Early development of biological indicators, p. 31-464. In: S.L. Loeb and A. Spacie (eds), Proc. Symp. on Biological Monitoring of Aquatic Systems.

Ravera O, 1991. Influence of heavy metals on the reproduction and embryonic development of freshwater pulmonates (Gastropoda; Mollusca) and cladocerans (Crustacea; Arthropoda). Comp. Biochem. Phys. C 100:215-219.

Ravera O, 1994. Introduzione allo studio dell'ecologia. Ed. Cafoscarina, Venzia: 281 pp.

Ravera O, Giannoni L, 1995. Plankton as an indicator of the temporal variation of the Chernobyl fallout. Sci. Total Environ. 172:9-125.

Ravera O, 1996. Zooplankton and trophic state relationships in temperate lakes. Mem. Ist. Ital. Idrobiol. 54: 195-212.

Ravera O, 1999. Biological monitoring by biodiversity and pollutant accumulator organisms, p. 473-478. In: A. Farina (ed.), Perspectives in ecology. Backhuys.

Ravera O, 2001. A comparison between diversity, similarity and biotic indices applied to the macroinvertebrate community of a small stream: the Ravella River (Como Province, Northern Italy). Aquat. Ecol. 35:97-107.

Ravera O, 2004. Importance and difficulties of research on metal speciation in the aquatic ecosystem: an ecologist's viewpoint. Annali Chimica 94:495-504.

Mosello R, de Bernardi R, Ravera O, 2011. Richard A. Vollenweider: contribution to our knowledge of Italian lakes. Aquat. Ecosyst. Health 14:174-178. 